\title{
Cutaneous metastasis from internal carcinomas: a review of 45 years
}

Metástases cutâneas de carcinomas internos: revisão de 45 anos

Jose Alexandre de Souza Sittart ${ }^{1}$
Monica Senise ${ }^{2}$

\begin{abstract}
BACKGROUND: cutaneous metastases are not so frequent and in the medical literature there are several communications of isolated cases, thereby we decided to continue our study initiated in 1981 (45 years).

OвJестіVE: our objective is to present the research and review of cutaneous metastases of 45 years through our archives at Hospital do Servidor Publico Estadual de Sao Paulo.

METHODS: the data were collected from clinical cases registered in our archives at anatomopathology department. RESULTS: since 1963 we have registered 209 patients with cutaneous metastases being the anterior thorax region the most affected area and in second place the abdominal region. Breast cancer was responsible for most of the cases in women and the lung in men.

CONCLUSION: this study represents a signioficant number of cases in medical practice because skin metastases of internal carcinomas rarely are observed and the great predominance, mainly due of his origin were represented by adenocarcinomas.
\end{abstract}

Keywords: Carcinoma; Neoplasm metastasis; Peer review; Skin

Resumo FunDAMENTOS: metastases cutaneas não são muito frequentemente descritas na literatura e em geral como casos isolados, nossa observação se iniciou em 1981 tendo registrado todos os casos observados no periodo de 45 anos.

OвJETIVO: apresentar a pesquisa e revisão de metastases cutaneas no período de 45 anos em pacientes do Hospital do Sevidor Publico Estadual de São Paulo.

MÉTodos: os dados foram coletados a partir do registro do Serviço de Anatomia Patologica.

RESULTADOS: desde 1963 foram registrados 209 pacientes com metastases cutaneas de carcinomas internos, sendo que a região toracica anterior foi a mais acometida e em segundo plano a região abdominal. Cancer de mama foi o responsavel pela maioria dos casos em mulheres e pulmão nos homens.

CONCLUSÃo: este estudo representa um numero significativo de casos, pois na pratica medica raramente são observadas metastases de carcinomas internos sendo que a grande maioria,principalmente por sua origem foi predominantemente representada pelos adenocarcinomas.

Palavras-chave: Carcinoma; Metástase neoplásica; Pele; Revisão por pares

Received on 12.04.11.

Approved by the Advisory Board and accepted for publication on 02.10.2012.

* Work performed at the Hospital do Servidor Público Estadual de São Paulo - São Paulo (SP), Brasil.

Financial support: none.

Conflict of interests: none.

Doctor - Director of the Dermatologic Department from Hospital do Servidor Publico Estadual de Sao Paulo - Sao Paulo (SP), Brazil.

MD- Private Praxis - Sao Paulo (SP), Brazil.

(C2013 by Anais Brasileiros de Dermatologia 


\section{INTRODUCTION}

Metastasis is defined as a neoplastic lesion coming from another cancerous growth, with which it is no longer in continuity. Metastatic dissemination to the skin may occur in the following ways: lymphatic spread, hematogenous spread, direct contiguity and, rarely, iatrogenic implantation. ${ }^{1,2}$ Cutaneous metastases are not so frequent. According to Lookingbill, they may arise before the identification of a primary neoplasm or concomitantly in $25.1 \%$ of cases, but in general later in the course of the disease. ${ }^{3}$ They may also be the first clinical manifestation, which makes it important to check this possibility. Therefore, the search for the neoplasm is essential.

The purpose of this study was to determine which primary tumors are more commonly related to skin metastases in males and females as well as the sites where they usually appear.

\section{MATERIALS AND METHODS}

A retrospective study on the cutaneous cases of metastases from internal carcinomas was carried out. Melanoma, lymphatic spread, hematogenous spread, cutaneous direct involvement by direct extension of the tumor and iatrogenic implantation were excluded.

The data were collected from the register of skin biopsies of the Laboratory of Dermatopathology at Hospital do Servidor Publico Estadual - Sao Paulo, Brazil, from 1963 to 2008 and from patients' medical handbooks available in the general archives of the hospital. We did not separate patients according to race, but there was a predominance of Caucasians.

The casuistry found was 209 patients and 216 cases. This difference is explained by the fact that the same patient presented metastases in different localizations, which were distant from each other. Of the total number $144(68.89 \%)$ patients were women and 65 $(31.10 \%)$ were men. Their age varied from 8 to 99 years.

\section{RESULTS}

In this study of 209 patients with cutaneous metastases, we observed that the most affected region was the anterior portion of the thorax, with 69 cases $(31.94 \%)$, followed by the abdominal region, with 44 cases $(20.37 \%)$, and the scalp, with 32 cases $(14.81 \%)$, as shown in table 1 . Breast cancer was the major responsible for cutaneous metastases in women, with 91 cases $(63.19 \%)$. In men, the major primary tumor was located in the lungs, with 22 cases $(33.84 \%)$. The other results are summarized in tables 2 and 3.

\section{DISCUSSION}

Metastases are the major cause of morbimortality in patients with cancer. Although we accept that metastases are rare, their exact frequency is not
TABLE 1: Anatomic localization of metástases

\begin{tabular}{lcc}
\hline & Absolute number & Percentage \\
\hline Anterior thorax & 69 & $31.94 \%$ \\
Abdomen & 44 & $20.37 \%$ \\
Scalp & 32 & $14.81 \%$ \\
Neck & 19 & $8.79 \%$ \\
Posterior thorax & 15 & $6.94 \%$ \\
Superior members & 14 & $6.48 \%$ \\
Pelvis region & 8 & $3.70 \%$ \\
Axillary region & 6 & $2.77 \%$ \\
Inferior members & 4 & $1.85 \%$ \\
Face & 4 & $1.85 \%$ \\
Ear & 1 & $0.46 \%$ \\
\hline Total & 216 & $100 \%$ \\
\hline
\end{tabular}

known. Also, they can have different origins depending on the studied ethnic population., ${ }^{3,4}$ We had previously carried through 2 retrospective studies, which were published in 1981 and 1998, totalizing a period of 27 years. With this one, we complete a review of 45 years. ${ }^{5,6}$

Breast cancer, the most prevalent neoplasm among female individuals, is also the main source of cutaneous metastasis. In our review, we did not include cases of individuals who had already had a breast tumor and cutaneous metastases due to contiguity. These cases are often difficult to evaluate, but we have observed that women previously treated for breast carcinoma need constant evaluation and require a skin biopsy on the slightest suspicion of a lesion.

Among men, the major cause of metastasis is lung cancer, although prostate cancer is more common. In our casuistic, its percentile has even increased (1981 - 24.24\%, $1992-21.95 \%$ and $2008-33.84 \%)$. It is known that the most frequent visceral tumors are the ones that most cause skin metastases. The abdominal region was the main site for metastases originated from tumors of the pancreas, intestine, lungs, breasts and ovaries.

The scalp was affected by metastasis in 32 patients $(14.81 \%)$ and originated from the intestine, breasts, stomach and kidneys. The face and ear were the least affected sites, with only 1 case for each site, which corresponds to $0.46 \%$ of the total number of cases. In 20 cases $(9.56 \%)$, it was not possible to determine the origin of the primary tumor through the 
TABLE 2: Localization of primary tumors in women

\begin{tabular}{|c|c|c|}
\hline \multirow[t]{2}{*}{ ORGAN } & \multicolumn{2}{|c|}{ NUMBER } \\
\hline & $\mathbf{N}$ & $\%$ \\
\hline Breast & 91 & $63.19 \%$ \\
\hline Large intestine & 15 & $10.41 \%$ \\
\hline Lung & 6 & $4.16 \%$ \\
\hline Ovary & 4 & $2.77 \%$ \\
\hline Uterus & 4 & $2.77 \%$ \\
\hline Pancreas & 3 & $2.08 \%$ \\
\hline Endometrium & 2 & $1.38 \%$ \\
\hline Kidney & 2 & $1.38 \%$ \\
\hline Urethra & 1 & $0.69 \%$ \\
\hline Tongue & 1 & $0.69 \%$ \\
\hline Stomach & 1 & $0.69 \%$ \\
\hline Thyroid & 1 & $0.69 \%$ \\
\hline Vulva & 1 & $0.69 \%$ \\
\hline Indeterminate & 12 & $8.33 \%$ \\
\hline Total & 144 & $100 \%$ \\
\hline
\end{tabular}

available ways. In 1981, the indeterminate ones were $12 \%$; in $1992,11.18 \%$; and in $2008,9.56 \%$, demonstrating a small improvement in the detection of the primary tumor.

Cutaneous lesions have a wide variety of clinical appearances, often simulating benign lesions, as the case of a patient who was referred to our Dermatology Service with the suspicion of herpes zoster, but who presented zosteriform cutaneous metastases from a stomach carcinoma. ${ }^{7}$ The lesions are more commonly ulcerated nodules of irregular shape and firm consistency. They are accompanied by scars, present a sclerodermiform aspect and changeable dimensions. In general, they are painless and not adherent to deeper surfaces. They can suffer erosion or ulceration, be single or multiple, grouped or not.

Although many metastatic carcinomas can be recognized through histopathological findings, an immunohistochemical analysis is often very useful. Although cutaneous metastases rarely reveal the site of the primary tumor, they can often indicate its origin.

In reality, the skin is not the main target of metastasis from internal carcinomas. The dissemination is much more frequent to organs such as the liver, lungs, organs of the gastrointestinal tract, bones, kid-
TABLE 3: Localization of primary tumors in men

\begin{tabular}{lll}
\hline ORGAN & \multicolumn{2}{c}{ NUMBER } \\
\cline { 2 - 3 } & $\mathbf{N}$ & $\%$ \\
\hline Lung & 22 & 33.84 \\
Stomach & 8 & 12.30 \\
Larynx & 5 & 7.69 \\
Kidney & 4 & 6.15 \\
Esophagus & 3 & 4.61 \\
Large intestine & 2 & 3.07 \\
Pancreas & 2 & 3.07 \\
Tongue & 1 & 1.53 \\
Testicles & 1 & 1.53 \\
Prostate gland & 1 & 1.53 \\
Bladder & 1 & 1.53 \\
Parotid gland & 1 & 1.53 \\
Mouth & 1 & 1.53 \\
Thyroid & 1 & 1.53 \\
Tonsil & 1 & 1.53 \\
Suprarenal & 1 & 1.53 \\
Breast & 1 & 1.53 \\
Indeterminate & 8 & 12.30 \\
\hline Total & 65 & 100 \\
\hline
\end{tabular}

neys, pancreas, ovaries and ganglia. Cutaneous metastasis may be a foretell signal yhat can be supervened untill one year after its detention. In spite of the great technological advances in the field of Medicine with regard to sophisticated examinations and new antineoplastic therapies, as supported by other authors, our statistical data show that there have not been great changes in the past 45 years in relation to origin, location, identification and metastases of carcinomas. ${ }^{8}$

With the recent inquiries about the codification of the human genome and study of the genes, prevention, identification and characterization of tumors and their consequent metastases, we will probably be able to detect or prevent them prematurely in the future.

At last, when the first clinical manifestation of visceral neoplasia is a cutaneous lesion, the patient's sex, age, localization and histopathological examination of the lesion are essential for tracking the primary tumor.

\section{CONCLUSION}

Despite the great advances in technology, recent new exams and antineoplastic drugs, we have not found many changes concerning the origin, identification and location of cutaneous metastases from carcinomas. 


\section{REFERENCES}

1. Textier L, Geniaux M, Tamisier JM, Delaunay MM, Plante C. Metastases cutanees des cancer digestifs. Ann DermatolVenereol. 1978;105:913-9.

2. Lookingbill DP, Spangler N, Sexton FM. Skin involvement as the presenting sign of internal carcinomas. J Am Acad Dermatol. 1990;22:19-26.

3. Hu SC, Chen GS, Lu YW, Wu CS, Lan CC. Cutaneous metastases from different internal malignancies: a clinical and prognostic appraisal. J Eur Acad Dermatol Venereol. 2008;22:735-40.

4. Hu SC, Chen GS, Wu CS, Chai CY, Chen WT, Lan CC. Rates of cutaneous metastases from different internal malignancies: Experience from a Taiwanese medical center. J Am Acad Dermatol. 2009;60:379-87.

5. Sittart JAS, Stávale JN, Massuda LT. Cutaneous metastasis of carcinomas. AMB Rev Assoc Med Bras.1981;27:61-2.

6. Sittart JAS, Criado PR, Ivanov MI, Ananias MTP. Metástases cutâneas de carcinomas internos. Med Cut ILA. 1995;23:11-4.

7. Sittart JAS, Silva ACG, Juang JM, Pires MC, Valente NYS. Zosteriform cutaneous metastasis of adenocarcinoma. Rev Bras Clín Terap. 1998:24:222-4.

8. Marcoval J, Moreno A, Peyri J. Cutaneous infiltration by cancer. J Am Acad Dermatol. 2007:57:577-80.
MAILING ADDRESS:

Jose Alexandre de Souza Sittart

Rua Borges Lagoa $n^{\circ} 1755,4^{\circ}$ andar

04038-034 - Vila Clementino - SP

Brazil

E-mail: jasittart@uol.com.br

How to cite this article: Sittart JAS, Senise M. Cutaneous metastasis from internal carcinomas: a review of 45 years. An Bras Dermatol. 2013;88(4):541-4. 